\title{
THE INCREASE OF TEACHER'S COMMITMENT TO THE ORGANISATION Through SERVANT LEADERSHIP REINFORCEMENT OF THE PRINCIPAL AND JOB SATISFACTION
}

\author{
Sutji Harijanto ${ }^{1)}$, B. Dwi Yuniar Rahmawaty ${ }^{2)}$ Muhammad Entang ${ }^{3)}$ \\ 1) Pakuan University, Indonesia \\ E-mail: sutjihar@unpak.ac.id \\ 2) Pakuan University, Indonesia \\ E-mail: bdwiyuniarr@gmail.com \\ 1) Pakuan University, Indonesia \\ E-mail: muhamadentang@yahoo.com
}

\begin{abstract}
The purpose of this study is to empirically determine the improvement of teacher's commitment to the organisation by observing its connection with servant leadership of the principal and job satisfaction, with respondents being Permanent Teachers of the Foundation (GTY) of Private Junior High School in Cibinong District, Bogor Regency. The number of research samples of 183 teachers was taken randomly using the proportional random sampling technique. The method used was the correlation method. Hypothesis testing was carried out using parametric statistical analysis in simple and multiple linear regression analysis, simple and multiple correlation analysis, and partial analysis with a significance level of $=0.01$ and $=0.05$. This study resulted in four conclusions. First, there is a significant positive correlation between servant leadership $\left(\mathrm{X}_{1}\right)$ and teacher's commitment to the organisation $(\mathrm{Y})$, which is indicated by a simple linear regression equation $\hat{Y}=63.094+0,501 X_{1}$. with correlation coefficient $r_{y 1}=0.73$, coefficient of determination $\mathrm{R}_{\mathrm{y} 1}{ }^{2}=0.5361$. Second, there is a very significant positive correlation between job satisfaction (X2) and teacher's commitment to the organization $(\mathrm{Y})$ which is indicated by the linear regression equation $\hat{\mathrm{Y}}=56.35+0.552 \mathrm{X} 2$ with correlation coefficient $\mathrm{r}_{\mathrm{y} 2}=0.66$, coefficient of determination $\mathrm{R}_{\mathrm{y} 2}{ }^{2}=0,4343$. Third, there is a significant positive correlation between servant leadership and job satisfaction collectively with the teacher's commitment to the organisation, which is indicated by the equation $\hat{\mathrm{Y}}=35.50+0.372 \mathrm{X} 1+0.34 \mathrm{X} 2$ with a correlation coefficient $\mathrm{r}^{\mathrm{y} .12}=0.81$ and coefficient of determination $\mathrm{R}_{\mathrm{y} .12}{ }^{2}=0.665$. Fourth, commitment to the organisation of GTY's Private Junior High School in Cibinong District, Bogor Regency can be enhanced through strengthening servant leadership and job satisfaction.
\end{abstract}

Keywords: Organisational Commitment; Servant Leadership; Job Satisfaction

\section{INTRODUCTION}

Commitment to the organisation can be formed due to several factors, both external and internal sources. A strong commitment will prompt organisational members' behaviour changes according to the organisation's goals. Organisational members will rarely "be absent", and the most important thing is that work productivity results are high. The members' strong commitment to the organisation can be observed through indications of members high participation in organisational activities and development as well as the amount of loyalty and responsibility of members to their work; thus, members of the organisation will do their job to the best of their ability solely to achieve organisational goals. That is why members' commitment to the organisation can be recognised from work activities and work results.

The teacher shows the teacher's commitment to the task through the tendency and willingness to carry out their duties and functions with high responsibility actively. Teachers with good task commitments will attempt to carry out their duties and responsibilities properly to the end. As a form of commitment to his/her duties, a teacher is always involved in school activities. If the teacher's commitment is low, the process of achieving student learning outcomes will be disrupted. 
The teacher's commitment to the organisation is shown when a teacher performs his/her teaching duties and also his/her duties as part of the school organisation. A teacher is said to be a professional who must have a high organisational commitment, characterised by a strong desire to remain a member of the organisation, accept the organisation's goals, and strive to advance the organisation. School is an organisation required to produce students who can live and compete in society. In this effort, schools are required to provide knowledge and skills to students. Educating and teaching becomes an inseparable part of the routine of a teacher as part of the school organisation.

Referring to the results of an initial survey conducted by the researcher on 01-03 February 2020 with 30 GTY respondents at an A-accredited private junior high school in Cibinong District, Bogor Regency, resulting in facts about teacher creativity as follows:

TABLE 1

FACTS ON TEACHERS' LOW COMMITMENT

\begin{tabular}{lll}
\hline NO & Indicators of Teachers Creativity & Percentage \\
\hline 1. & Current working conditions & $38 \%$ \\
2. & Meeting expectations & $33 \%$ \\
3. & Benefits received & $30 \%$ \\
4. & Individual Values & $42 \%$ \\
5. & Reason of obligation & $35 \%$ \\
\hline
\end{tabular}

Observing at the table above, it is apparent that the commitment of teachers in schools is problematic, including 1) $38 \%$ of teachers are not optimal in their current working conditions, 2) $33 \%$ of teachers are not optimal in meeting expectations, 3) $30 \%$ of teachers are not optimal in the benefits received, 4 ) $42 \%$ of teachers are not optimal regarding individual values, and 5) $35 \%$ of teachers are not optimal in terms of the obligation. Thus, the realisation in the field is that many teachers are still not optimal in carrying out their work commitments.

The objectives of this study are: 1) to determine the strength of the correlation between servant leadership and organisational commitment, 2) to determine the strength of the correlation between job satisfaction and organisational commitment, 3) to determine the strength of the correlation between servant leadership and job satisfaction collectively with organisational commitment, and 4) to determine the increase in commitment to the organisation through strengthening servant leadership and job satisfaction

With the consideration of these conditions, it is necessary to analyse the various variables that also affect the quality of education, especially in terms of teacher creativity. This is why the author is interested in conducting research with the title: The Increase Of Teacher's commitment To The Organization Through Servant Leadership Reinforcement Of The Principal And Job Satisfaction of GTY at A-Accredited Private Junior High School in Cibinong District, Bogor Regency.

The theory of experts on commitment, including Colquitt, Lepine, and Wesson (2011: 69-78), explains that commitment to the organisation is the individual's desire to remain a member of the organisation. Commitment to the organisation is one of the determining factors whether he/she is willing to remain a member of the organisation or tries to leave (looking for work in other organisations). According to Dharma (2019: 348-362), Organisational commitment refers to the bond of power that drives individuals towards certain actions to achieve certain goals. Another opinion according to Adiapsari (2012: 8) states that if employees have organisational commitment, they will show a willingness to work hard to achieve organisational goals and have a strong desire to work and remain in the institution where they work individually through the work environment. According to Arniansyah, Gita Widya Laksmini Soerjoatmodjo (2018: 23 ), there are two types of organisational commitment, i.e. affective commitment and continuance commitment. Affective commitment is the emotional attachment, identification, and involvement of employees in a particular organisation.

Danish et al. (2015: 102-109) explains that "Organisational commitment can be defined as optimistic moods of identification with, affection to and engrossment in the work of the organisation, a sense of responsibility to the organisation and the level to which employee's sense attachment to the organisation when they reflect the price of departure from the organisation." From the statement above, commitment is an identification of an optimistic mood with compassion and concern in the work of the organisation, a sense of responsibility towards the organisation, and the degree to which employees' sense of attachment to the organisation reflects the price of moving/resigning/leaving the organisation.

Quoted from Salim Musabah Bakhit Al Zefeiti, Noor Azmi Mohamad (2017:13-14), organisational commitment is one of the approaches that can lead to high performance. Employees committed to their organisation are more likely to perform better than less committed employees because they put more effort on behalf of the organisation towards its success and strive to achieve its goals and mission.

Griffin (2013: 454), commitment to the organisation is employees' behaviour that reflects their attachment to the organisation. Kreitner and Kinicki (2010:166), commitment to the organisation is a committed individual who is expected to show a desire to work harder to achieve organisational goals and a greater desire to remain working in an organisation. The same thing about organisational commitment was also expressed by Luthans (2011: 147); someone who is committed shows a willingness to work harder to achieve organisational goals and a great desire to continue working in the organisation.

Gibson, Ivancevich, Donelly, and Konopaske (2012: 182), "... a sense of identification with organisation goals, a feeling of involvement in organisational duties, and a feeling of loyalty for the organisation". In organisational commitment, apart from being involved in carrying out tasks according to organisational goals, there is also loyalty to the organisation. According to Vania Claresta Prabowo and Roy Setiawan (2013:2-3), organisational commitment is a condition or degree to which an employee favours a particular 
organisation with its goals and maintains membership within that organisation.

Mowday (2017:10-11) explains that "Organisational commitment is 'the relative strength of an individual's identification with and involvement in a particular organisation'. (Organisational commitment is the 'relative strength of an individual's identification and involvement in a particular organisation'.

Based on the theoretical explanation above, it can be synthesised that the teacher's commitment to the organisation is a teacher's desire to identify the teacher's involvement in the organisation to determine its goals and show loyalty to survive in an organisation. The measurement can be done through the following indicators: 1) current working conditions, 2) meeting expectations, 3) benefits received, 4) individual values, 5) reasons of obligation.

While the operational definition of a teacher's commitment to the organisation is a teacher assessment to identify teacher involvement within the school in order to determine their goals and show their loyalty to survive in a school, which is measured by an instrument in the form of a questionnaire with indicators: 1) current working conditions, 2) meeting expectations, 3) benefits received, 4) individuals values, 5) reasons of obligation.

Gary E. Robert (2015: 3-4) defines servant leadership as leader behaviour that has the main character attributes including moral integrity, empathy, humility, authenticity, trust, hope, courage, and forgiveness, and complementary attributes include empowerment, listening actively, setting goals and building relationships. Steven L. McShane (2018: 344) defines servant leadership as a leader who believes that leaders must serve followers, not the other way around; Leaders help employees meet the needs of followers; they are coaches, stewards, and facilitators of employee development.

John M Ivancevich and Michael T Matteson (2013: 457) state that servant leadership refers to the behaviour of a leader who emphasises employee growth and service as the most important thing; leaders put the needs of others before their own needs. Nixon (2017:3) and Spears (2017:4) explain that servant leadership prioritises service and encourages good relationships by developing an atmosphere of dignity and respect, building community and teamwork, and listening to colleagues and employees.

Irfanullah Khan et al. (2016: $1-8)$ state ...... "the servant leader focuses on the followers' needs and helps them become more autonomous, freer and knowledgeable." In other words, servant leadership is a leader's behaviour that focuses on the needs of followers and assists them to become more independent and knowledgeable.

Servant leadership has unique elements and distinguishes it from other types of leadership as stated by Kent (2016:12) that servant leadership has (1) a moral component, meaning that morals become an integral part of the identity of the leader and are transferred or transmitted to their subordinates or followers; (2) focus on service to followers or subordinates, meaning that the leader focuses to the development, improvement and achievement of subordinates' performance and not just for the benefit of the organisation; (3) attention to the success of all stakeholders, meaning that organisational leaders view that organisational success cannot be separated from all internal and external components related to the organisation such as employees, customers, business partners and the community; and (4) self-reflection, as an effort to avoid an arrogant leader profile. Leaders who carry the servant leadership model provide openness for all their members and the organisations they lead to participate actively and creatively and generate great motivation for their employees to work and involve their hearts in the organisation's mission and goals.

Focht, Adam, and Michael Ponton (2015: pp 44-60) assert that servant leadership begins with a desire to provide services to individuals (followers) and then develops aspirations to direct individuals to certain goals. In other words, a leader's behaviour is based on the desire to serve and is driven by efforts to direct other individuals to certain goals.

According to Spears (2019:140-141), servant leadership is a leader who prioritises service, beginning with the natural feeling of someone who wants to serve and prioritise service. Furthermore, consciously, this choice brings aspirations and encouragement in leading others."

Based on the theoretical description above, it can be synthesised that servant leadership is a leader's behaviour originating from sincere feelings that arise from the heart to serve, placing the needs of followers as a priority, getting things done along with the others, and helping others in achieving a common goal. Factors that influence the existence of servant leadership include: 1) Altruistic calling (desire to help), 2) Emotional healing, 3) humility (low selfesteem), 4) trust, 5) listening (good listeners), 6 ) service, 7) vision.

While the operational definition of servant leadership is the teacher's assessment of the principal's behaviour arising from sincere feelings that emerge from the heart to serve, placing the needs of followers as a priority, getting things done with the others, and helping others in achieving a common goal, which is measured by an instrument in the form of a questionnaire with indicators: 1) Altruistic calling (desire to help), 2) Emotional healing 3) humility (humble) 4) trust 5) listening (good listener) 6) service 7) vision.

Colquitt, Lepine, and Wesson (2011: 104-126) suggest that job satisfaction is an individual's emotional condition arising from assessing his/her work or experiences at work. Howel and Robert (2010: 98) explain that job satisfaction is the overall result of how employees like or dislike various aspects of their work.

Robbins and Judge (2018:2) explain that job satisfaction is a good and positive feeling regarding work resulting from evaluating its characteristics. If someone considers he/she obtains high job satisfaction, he/she will have positive feelings towards his/her job, while someone who experiences low job satisfaction will obtain negative feelings.

Marihot Tua Effendi Hariandja (2018:211-226) explains that job satisfaction is the extent to which individuals feel positively or negatively toward various factors or 
dimensions of the tasks in their work., that working is not just doing work, but is also related to other aspects such as interactions with coworkers, superiors, obeying rules, and certain work environments that are often inadequate or unfavourable.

Sopiah (2008:170-172) explains that job satisfaction is a person's attitude and emotional response to work situations and conditions resulting from comparing what is expected with what is obtained from his/her work. Dr Meithiana Indrasari, ST, MM (2017:37), in the essay of her book, suggests that job satisfaction may be as pleasurable as a positive emotional state resulting from the appraisal of one's job or job experiences, a state resulting from the appraisal of one's job or job experiences, which means that job satisfaction is a positive emotional state or can please a person as a result of the results or assessment of one's work or experience during work.

Based on the theoretical description above, it can be synthesised that job satisfaction is a positive feeling in carrying out various aspects of work, which results from evaluating its characteristics. The indicators that can affect job satisfaction are 1) salary; 2) work environment; 3) promotion; 4) supervision; 5) coworkers.

While the operational definition of job satisfaction is the teacher's assessment of positive feelings in carrying out various aspects of work, which is the result of an evaluation of its characteristics, which is measured by an instrument in the form of a questionnaire with indicators of 1) salary; 2) work environment; 3) promotion; 4) supervision; 5) coworkers.

\section{METHODS}

This research uses a survey method with correlational techniques to determine whether the variables of servant leadership and job satisfaction positively correlate with teacher's commitment. The research was conducted on Permanent Teachers of the Foundation (GTY) of Private Junior High Schools with A-Accreditation in Cibinong District, Bogor Regency, in April 2020-October 2021, with a research population of 334 and a sample of 183 teachers. Sampling in each school was carried out using the proportional random sampling technique. The research data were analysed using descriptive and inferential statistics. Data analysis commenced with requirements analysis, i.e., normality test of estimated error and homogeneity of variance test then advanced with the determination of the regression equation, regression equation significance test, regression linearity, and hypothesis testing with correlation test using ANOVA table. The data results in the field will be classified by indicator; thus, they can be compared and analysed using the SITOREM method.

\section{RESULT AND DISCUSSION}

\section{A. Teacher's commitment $(Y)$}

The teacher's commitment variable based on the results of the research score obtained by the respondents is presented in the statistical description as follows:

TABLE 2

STATISTICS DESCRIPTION OF TEACHER'S COMMITMENT (Y)

\begin{tabular}{ll}
\hline Criteria & Value \\
\hline Mean & 128,74 \\
Standard Error & 0,85 \\
Median value & 128 \\
Frequently Appearing Values & 129 \\
Standard Deviation & 11,60 \\
Variant & 134,57 \\
Tailedness & $-0,37$ \\
Degree of inclination & 0,22 \\
Score Range & 54 \\
Lowest Value & 101 \\
Highest Value & 155 \\
\hline Amount & 23560 \\
Amount of Data & 183 \\
\hline
\end{tabular}

The score of the teacher's commitment variable is based on the respondents' answers to the teacher commitment instrument items consisting of 36 statements that have a scale between 1 to 5 .

Based on the research data that has been carried out, it is known that the highest empirical score achieved by 183 respondents was 155. The lowest empirical score was 101 . While the empirical average score was 128.74 , the empirical range was 54, the empirical mean score was 128 , the frequently occurs empirical mean score is 129 , the empirical variance score is 134.57 , and the empirical score of the standard deviation is 11.60 . From the calculation results, the number of interval classes obtained is 8 with an interval of 7 . The frequency distribution of teacher's commitment scores can be seen in table 2 .

TABLE 3

\begin{tabular}{lll} 
DATA FREQUENCY DISTRIBUTION OF TEACHER'S COMMITMENT (Y) \\
\hline Interval & Absolute & Percentage of \\
Class & Frequency (fi) & Pi (\%) \\
$101-107$ & 5 & 2,73 \\
$108-114$ & 12 & 6,56 \\
$115-121$ & 39 & 21,31 \\
$122-128$ & 37 & 20,22 \\
$129-135$ & 42 & 22,95 \\
$136-142$ & 23 & 12,57 \\
$143-149$ & 16 & 8,74 \\
$150-156$ & 9 & 4,92 \\
\hline Amount & 183 & $100 \%$ \\
\hline
\end{tabular}

Based on the data presented in the table above, the distribution of teacher's commitment scores can be displayed in the histogram graph in Figure 1. 


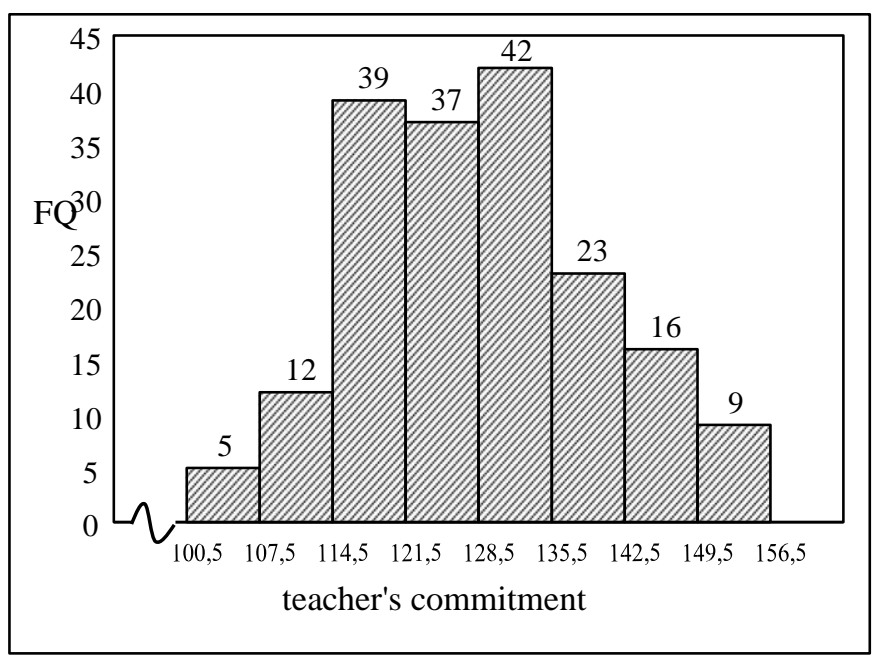

Figure 1. Data Frequency Histogram of Teacher's commitment (Y)

The variable instrument of teacher's commitment to the organisation is the dependent variable which consists of 36 valid statements. The lowest theoretical score is 36 (one multiplied by 36), and the highest score is 180 (five is multiplied by 36). The result of the calculation of the theoretical median is $(180+36) / 2=108$. While the lowest empirical score is 101, and the highest empirical score is 155 . The calculation result of the empirical median is $=128$. Thus the empirical median is greater than the theoretical median. This indicates that the variable of teacher's commitment to the organisation in this study tends to be high.

From the frequency distribution table, it can be explained that 90 people $(49.18 \%)$ were classified into the category of having a high teacher commitment to the organisation, i.e. in the score range $129-156$ people, 37 people $(20.22 \%)$ were classified into the category of having moderate teacher commitment to the organisation which can be seen in the score range $122-128$, and as many as $56(30.06 \%)$ teachers were classified into the category of having low teacher commitment to the organisation which can be seen in the score range of 101-121. The data explanation shows that the percentage of teachers with low teacher commitment to the organisation and the number of teachers with moderate teacher commitment to the organisation is still considerably high at $50.82(30.06 \%+20.22 \%)$.

\section{B. Servant Leadership (X1)}

The serving leadership variable based on the results of the research score obtained by the respondents is presented in the statistical description as follows:
TABLE 4

STATISTICS DESCRIPTION OF SERVANT LEADERSHIP (X1)

\begin{tabular}{ll}
\hline Criteria & Value \\
\hline Mean & 130,98 \\
Standard Error & 1,25 \\
Median value & 129 \\
Frequently Appearing Values & 125 \\
Standard Deviation & 16,94 \\
Variant & 287,18 \\
Tailedness & $-0,62$ \\
Degree of inclination & 0,30 \\
Score Range & 73 \\
Lowest Value & 96 \\
Highest Value & 169 \\
\hline Amount & 23970 \\
Amount of Data & 183 \\
\hline
\end{tabular}

Table 4 shows that the highest empirical score achieved by 183 respondents is 169 . The lowest empirical score is 96 . While the empirical average score is 130.98 , the empirical score range is 73 , the empirical mean score is 129 , the frequently appear empirical score is 125 , the empirical variance score is 287.18, and the empirical score of the standard deviation is 16.94 . From the calculation results, the number of interval classes obtained was 9 with an interval of 9. The frequency distribution of the servant leadership variable data can be observed in the following table:

TABLE 5

DATA FREQUENCY DISTRIBUTION OF SERVANT LEADERSHIP (X1)

\begin{tabular}{lll}
\hline $\begin{array}{l}\text { Interval } \\
\text { Class }\end{array}$ & $\begin{array}{l}\text { Absolute } \\
\text { Frequency (fi) }\end{array}$ & $\begin{array}{l}\text { Relative } \\
\text { Percentage (\%) }\end{array}$ \\
\hline $96-104$ & 7 & 3,83 \\
$105-113$ & 24 & 13,11 \\
$114-122$ & 30 & 16,39 \\
$123-131$ & 40 & 21,86 \\
$132-140$ & 29 & 15,85 \\
$141-149$ & 22 & 12,02 \\
$150-158$ & 19 & 10,38 \\
$159-167$ & 9 & 4,92 \\
$168-176$ & 3 & 1,64 \\
\hline Amount & 121 & $100 \%$ \\
\hline
\end{tabular}

The frequency distribution of each interval as shown in the table above can be shown in the following histogram: 


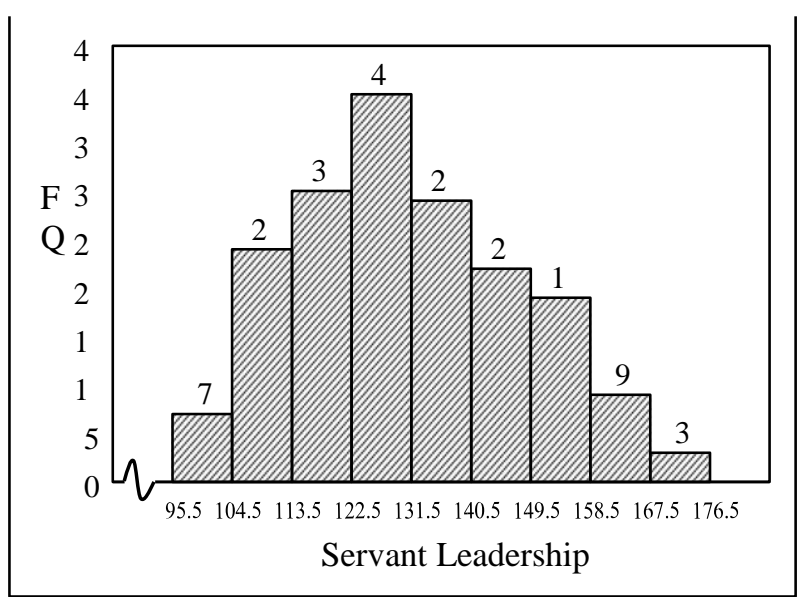

Figure 2. Data Frequency Histogram of Servant Leadership (X1)

The servant leadership variable instrument is an independent variable consisting of 35 valid statements. The lowest theoretical score is 35 (score of one multiplied by 35 ), and the highest score is 175 (score of five multiplied by 35 ). The calculation result of the theoretical median score is (175 + 35) $/ 2=105$ ). While the lowest empirical score is 96 , and the highest empirical score is 169 . The calculation result of the empirical median score is 129 . This indicates that servant leadership in this research is high.

From the frequency distribution table, it can be explained that 82 people $(44.81 \%)$ were classified into the category of having high servant leadership, i.e. in the score range of 132176. As many as 40 people $(21.86 \%)$ were classified into having moderate servant leadership, which can be seen in the score range of 123-131. In comparison, as many as 61 $(33.33 \%)$ teachers were classified into having low servant leadership which can be seen in the score range of 96-122. The data explanation shows that the percentage of teachers with low servant leadership and the number of teachers with moderate servant leadership was still considerably high at $55.19(33.33 \%+21.86 \%)$.

\section{Job Satisfaction (X2)}

The job satisfaction variable based on the results of the research score obtained by the respondents is presented in the statistical description as follows:

TABLE 6

STATISTICAL DESCRIPTION OF JOB SATISFACTION (X2)

\begin{tabular}{ll}
\hline Criteria & Value \\
\hline Mean & 131,18 \\
Standard Error & 1,02 \\
Median value & 130 \\
Frequently Appearing Values & 129 \\
Standard Deviation & 13,85 \\
Variant & 191,92 \\
Tailedness & $-0,32$ \\
Degree of inclination & 0,05 \\
Score Range & 64 \\
Lowest Value & 100 \\
Highest Value & 164 \\
\hline
\end{tabular}

\begin{tabular}{ll}
\hline Amount & 24007 \\
Amount of Data & 183 \\
\hline
\end{tabular}

The resulting score of the job satisfaction variable is based on respondents' answers to the job satisfaction instrument items consisting of 34 statement items with a scale between 1 to 5 .

The research data that has been carried out shows that the highest empirical value achieved by 183 respondents was 164. The lowest empirical value was 100 . While the empirical mean was 131.18 , the empirical value range was 64 , the median empirical value was 130 , the frequently appear empirical value was 129 , the empirical variance value was 191.92, and the empirical value of the standard deviation was 13.85 . The number of interval classes was 9 with an interval of 8 . The frequency distribution of selfefficacy scores can be seen in table 7 .

TABLE 7

\begin{tabular}{lll}
$\begin{array}{lll}\text { DATA FREQUENCY DISTRIBUTION OF JOB SATISFACTION }(\mathrm{X} 2) \\
\text { Interval }\end{array}$ & $\begin{array}{l}\text { Absolute } \\
\text { Class }\end{array}$ & $\begin{array}{l}\text { F Relative } \\
(\boldsymbol{\%})\end{array}$ \\
\hline $100-107$ & 8 & 4,37 \\
$108-115$ & 16 & 8,74 \\
$116-123$ & 24 & 13,11 \\
$124-131$ & 51 & 27,87 \\
$132-139$ & 40 & 21,86 \\
$140-147$ & 14 & 7,65 \\
$148-155$ & 24 & 13,11 \\
$156-162$ & 5 & 2,73 \\
$163-170$ & 1 & 0,55 \\
\hline Total & $\mathbf{1 8 3}$ & $\mathbf{1 0 0} \%$ \\
\hline
\end{tabular}

Based on the data presented in the table above, the distribution of job satisfaction scores can be displayed in the histogram graph in Figure 3

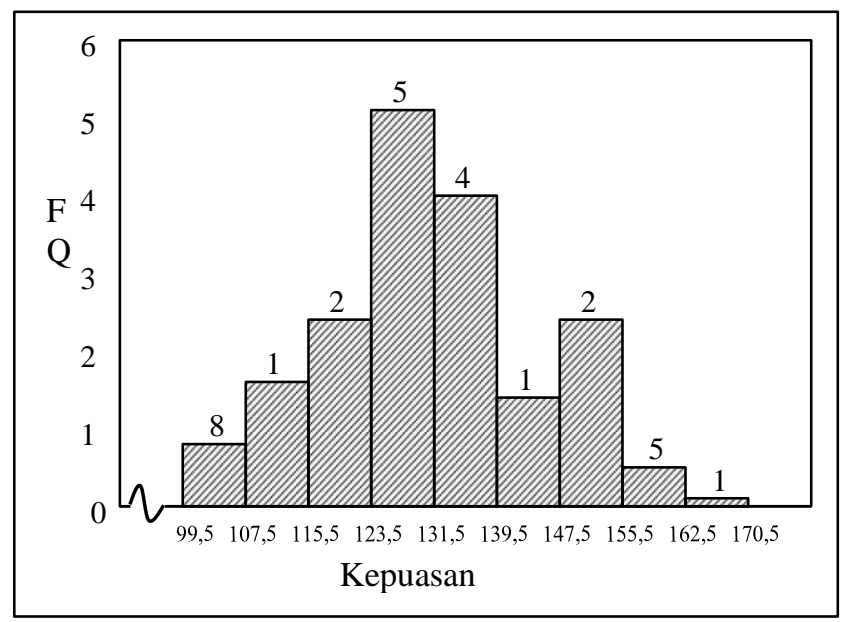

Figure 3. Data Frequency Histogram of Job Satisfaction (X2)

The instrument consists of 34 items. The lowest theoretical value is 34 (score of one multiplied by 34), and the highest score is 170 (score of five multiplied by 34 ). The calculation result of the theoretical median value is $(170+$ 
34) $/ 2=102$ ). While the lowest empirical value is 100 and the highest empirical value is 164 . The calculation result of the empirical median value is 130 . This indicates that the principal's job satisfaction at the GTY of A-Accredited Private Junior High School in Cibinong District, Bogor Regency in this study is relatively high.

TABLE 7

ANALYSIS OF VARIANCE (ANAVA) WITH REGRESSION EQUATION OF $\hat{Y}=$ $63,094+0,501 \mathrm{X}_{1}$

\begin{tabular}{|c|c|c|c|c|c|c|c|}
\hline \multirow[t]{2}{*}{ Variance Source } & \multirow[t]{2}{*}{ dk } & \multirow[t]{2}{*}{ JK } & \multirow[t]{2}{*}{ RJK } & \multirow[t]{2}{*}{ Fcount } & \multicolumn{2}{|l|}{ Ftable } & \multirow[t]{2}{*}{ Explanation } \\
\hline & & & & & $\alpha=$ & $\alpha=$ & \\
\hline Total & 183 & 3057682 & & \multirow[b]{3}{*}{$209,13^{* * *}$} & & & \multirow[t]{2}{*}{ Very Significan } \\
\hline Coefficient (a) & 1 & 3033189 & 3033189 & & 3,89 & 6,77 & \\
\hline Regression (b/a) & 1 & 13129.57 & 13129.57 & & 3 & 7 & \\
\hline Remainder & 181 & 11363,36 & 62,78 & \multirow{3}{*}{$0,70 \mathrm{~ns}$} & 1,43 & 1,65 & \multirow{3}{*}{$\begin{array}{l}\text { Non-significant } \\
\text { (Linear) }\end{array}$} \\
\hline Corelation & 60 & 2896,43 & 48,27 & & & & \\
\hline Error & 123 & 8466,93 & 68,84 & & & & \\
\hline $\mathrm{Dk}$ & \multirow{2}{*}{\multicolumn{7}{|c|}{$:$ degree of freedom }} \\
\hline JK & \multirow{2}{*}{\multicolumn{6}{|c|}{$\begin{array}{l}: \text { sum of squares } \\
\text { : mean sum of squares }\end{array}$}} & \\
\hline RJK & & & & & & & \\
\hline *** & \multicolumn{7}{|c|}{ : very significicant } \\
\hline
\end{tabular}

From the frequency distribution table, it can be explained that 84 people $(45.9 \%)$ rated high job satisfaction, i.e. in the score range of $132-170$, as many as 51 people $(27.87 \%)$ rated moderate job satisfaction, which can be seen in the score range of 124- 131, and as many as 48 (26.22\%) teachers rated low job satisfaction which can be seen in the score range of 100-123. The data explanation shows that the percentage of teachers who rated moderate job satisfaction and the number of teachers who rated moderate job satisfaction was still considerably high at $60.32(29.75 \%+$ $30.57 \%)$.

Positive Correlation between Servant Leadership (X1) and Teacher's Commitment ( $Y$ )

The results confirmed that there was a positive and significant correlation between servant leadership $\left(\mathrm{X}_{1}\right)$ and teacher's commitment ( $\mathrm{Y}$ ) in the form of a regression equation of $\hat{\mathrm{Y}}=63.094+0.501 \mathrm{X}_{1}$ with a correlation coefficient $r_{\mathrm{y} 1}=0.73$ and a determination coefficient $r_{\mathrm{y} 1}^{2}=$ 0.5361 , this means servant leadership variable contributes $53.61 \%$ to the teacher's commitment variable. Hence, increasing teacher commitment can be influenced by servant leadership.

Based on the research result above, it can be concluded that servant leadership makes a significant contribution to teacher's commitment. The higher the service leadership is predicted, the higher the teacher's commitment.

\section{Correlation between Job Satisfaction (X2) and Teacher's Commitment $(Y)$}

There is a positive and significant correlation between job satisfaction (X2) and teacher's creativity (Y) in the form of a regression equation of $\hat{\mathrm{Y}}=56.35+0.552 \mathrm{X} 2$ with a correlation coefficient $r_{\mathrm{y} 1}=0.66$ and a determination coefficient $\mathrm{r}_{\mathrm{y} 1}^{2}=0.4433$; this means the variable of Job satisfaction contributes $43.43 \%$ to the teacher's commitment variable. Thus to increase teacher's commitment can be influenced by job satisfaction.

Based on the research results above, it can be concluded that job satisfaction presents a significant contribution to teacher's commitment. The higher the job satisfaction is predicted, the higher the teacher's commitment.

TABLE 8

ANALYSIS OF VARIANCE (ANOVA) WITH REGRESSION EQUATION $\hat{Y}=56,35$

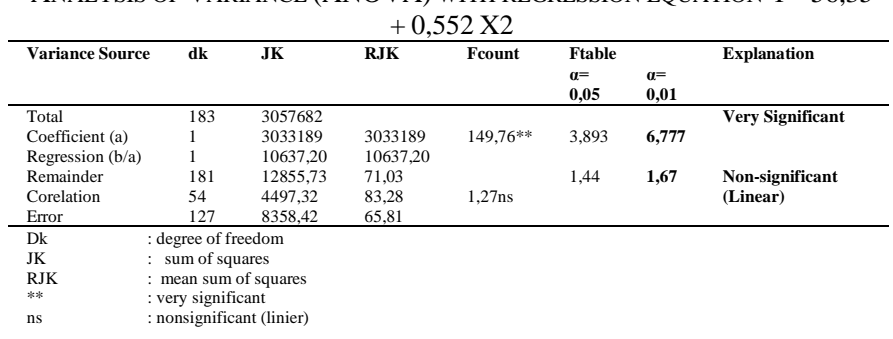

Correlation between Servant Leadership (X1) and Job Satisfaction (X2) collectively with Teacher's Commitment (Y)

There is a positive and significant correlation between servant leadership $\left(\mathrm{X}_{1}\right)$ and job satisfaction $\left(\mathrm{X}_{2}\right)$ concurrently with teacher's commitment $(\mathrm{Y})$ in the form of a regression equation $\hat{\mathrm{Y}}=35.50+0.372 \mathrm{X} 1+0.34 \mathrm{X} 2$, the strength of the correlation between the two $\mathrm{X}$ variables indicated by the value with the correlation coefficient $r_{y 12}=0.81$ and the coefficient of determination $\mathrm{r}_{\mathrm{y} 12}^{2}=0.665$, this means that the servant leadership variable and job satisfaction collectively contribute to teacher's commitment of $66.5 \%$ to the teacher's commitment variable.

The coefficient of determination of the servant leadership variable is relatively higher, i.e. $53.61 \%$, compared to the coefficient of determination of job satisfaction, which is $43.43 \%$. The difference in the value of the coefficient of determination of the two variables individually means that based on respondents' assessments, the servant leadership factor contributes more positively and significantly to teacher's commitment. While the value of the coefficient of determination of the servant leadership variable and job satisfaction collectively delivers a value of $66.5 \%$. This shows the meaning that according to the respondent's assessment, the two factors of servant leadership and job satisfaction collectively make a very significant contribution to the increase of teacher's commitment.

Based on the description above, servant leadership and job satisfaction collectively can increase teacher's commitment. The research is carried out to understand how much strength each indicator has for each variable by assigning a weighting to each indicator based on the SITOREM theory.

TABLE 9. ANOVA FOR MULTIPLE REGRESSION SIGNIFICANCE TEST WITH EQUATION OF

\begin{tabular}{|c|c|c|c|c|c|c|c|}
\hline $\begin{array}{l}\text { Variant } \\
\text { source }\end{array}$ & Dk & JK & (RJK) & Fcount & $\begin{array}{l}\text { Ftable } \\
a= \\
\mathbf{0 . 0 5}\end{array}$ & $\begin{array}{l}\alpha= \\
0.01 \\
0.01\end{array}$ & Conclusion \\
\hline Regression & 2 & 16283,57 & 8141,78 & $178,5^{* * *}$ & 3,05 & 4,81 & \\
\hline Error & 180 & 8209,355 & 45,6075 & & & & $\begin{array}{l}\text { Very } \\
\text { Significant }\end{array}$ \\
\hline Total & 182 & 24492,93 & & & & & \\
\hline
\end{tabular}




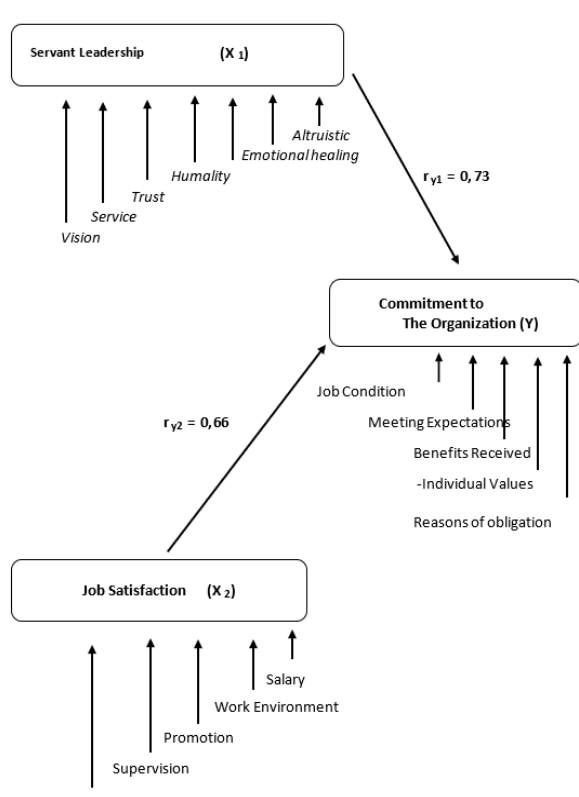

Figure 4. SITOREM Analysis Results

TABLE 10

SITOREM ANALYSIS RESULTS

\begin{tabular}{|c|c|c|}
\hline \multicolumn{3}{|c|}{ TEACHER'S COMMITMENT TO THE ORGANISATION } \\
\hline Indicator in Initial State & Indicator After Weighting By expert & Indicator Value \\
\hline Current working conditions & 1 st Benefits received ( $22 \%$ ) & 4,13 \\
\hline Meeting expectations & 2nd Current working conditions ( $21 \%$ ) & 4,06 \\
\hline Benefits received & 3rd Meeting expectations $(19 \%)$ & 4,03 \\
\hline Individual Values & 4th Individual Values $(19 \%)$ & 2,85 \\
\hline Reasons of obligation & 5 th Reasons of obligation (18\%) & 2,71 \\
\hline \multicolumn{3}{|c|}{ SERVANT LEADERSHIP $(\mathrm{ry} 1=0,73)$} \\
\hline Indicator in Initial State & Indicator After Weighting By expert & Indicator Value \\
\hline Altruistic calling & 1st Service $(18 \%)$ & 4,16 \\
\hline Emotional healing & 2 nd Trust $(17 \%)$ & 4,19 \\
\hline Humanity & 3rd Altruistic calling (14\%) & 4,15 \\
\hline Trust & 4 th Listening $(14 \%)$ & 3,30 \\
\hline Listening & 5th Emotional healing (13\%) & 4,02 \\
\hline Service & 6th Vision $(12 \%)$ & 3,26 \\
\hline Vision & 7 th Humanity $(11 \%)$ & 2,95 \\
\hline \multicolumn{3}{|c|}{ JOB SATISFACTION $(\mathrm{ry} 2=0,66)$} \\
\hline Indicator in Initial State & Indicator After Weighting By expert & Indicator Value \\
\hline Salary and Incentives & 1st Salary and Incentives $(24 \%)$ & 4,20 \\
\hline Work Environment & 2nd Promotion (22\%) & 3,78 \\
\hline Promotion & 3rd Work Environment (20\%) & 3,57 \\
\hline Supervision & 4th Supervision $(18 \%)$ & 4,17 \\
\hline $\begin{array}{l}\text { Coworkers } \\
\text { Cown }\end{array}$ & 5 th Coworkers $(16 \%)$ & $\begin{array}{r}3,417 \\
3,49-10\end{array}$ \\
\hline Maintained Indicators & \multicolumn{2}{|l|}{ Indicator priority Improved } \\
\hline 1st Service & \multicolumn{2}{|l|}{ 1st Humanity } \\
\hline 2nd Trust & \multirow{2}{*}{\multicolumn{2}{|c|}{ 2nd Vision }} \\
\hline 3rd Altruistic calling & & \\
\hline 4th Emotional healing & \multicolumn{2}{|l|}{$\begin{array}{l}\text { 3rd Listening } \\
\text { 4th Coworkers }\end{array}$} \\
\hline 5th Salary and Incentives & \multicolumn{2}{|l|}{$\begin{array}{l}\text { 4th Coworkers } \\
\text { 5th Working Environment }\end{array}$} \\
\hline 6th Supervision & \multicolumn{2}{|l|}{ 6th Promotion } \\
\hline 7th Benefits Received & \multicolumn{2}{|l|}{ 7th Reasons of Obligation } \\
\hline 8th Current Working Condition & \multirow{2}{*}{\multicolumn{2}{|c|}{ 8th Individual values }} \\
\hline 9th Meeting Expectations & & \\
\hline
\end{tabular}

\section{CONCLUSIONS}

The results show that there was a strong and significant positive correlation between servant leadership and teacher's creativity with a correlation coefficient $\rho \mathrm{yx}_{1}=0.73$; there is a strong and significant positive correlation between job satisfaction and teacher's creativity with a correlation coefficient of $\rho \mathrm{yx}_{2}=0.66$, and there is a strong and significant positive correlation between servant leadership and job satisfaction collectively with teacher's creativity with a correlation coefficient of $\rho \mathrm{yx}_{3}=0.665$. This shows that teacher's creativity can be enhanced through servant leadership and job satisfaction. It is concluded that teacher's creativity can be improved by developing servant leadership and job satisfaction and from the component of teacher's creativity itself.

\section{REFERENCES}

Ansor. (2009). Analisis Pengaruh ROA, PBV, EPS, PER, Kurs dan Suku Bunga terhadap Return Saham (Kajian Empiris pada Perusahaan Manufaktur yang Terdaftar di BEI Tahun 2006-2008). Master's thesis. Semarang: Program Pascasarjana Magister Manajemen Universitas Diponegoro.

Bodie, Z., A, Kane., and A, J. Marcus. (2002). Investments. Boston: McGraw Hill.

Brav, A., \& Heaton, J.B. (2002). Competing Theories of Financial Anomalies. Review of Financial Studies 15, 575-606.

Campbell, R. H., Lins, K. V., \& Roper, A. H. (2004). The Effect of Capital Structure When Expected Agency Costs are Extreme. Journal of Financial Economics, $445-460$.

Adiapsari, R. (2012). Analisis pengaruh Iklim Organisasi Terhadap Komitmen dengan Kepuasan Kerja Sebagai variabel Mediasi Pada Karyawan PT. Tiga Serangkai Solo. Riset Manajemen dan Akuntansi. Vol. 3 No. 5, Mei.

Colquitt, J.A., Jeffery A.L., and Michael J.W. (2017). 4 "Organizational: Improving Performance and Commitment in the Workplace”,Fifth Edit. New York: McGraw-Hill Education.

Danish, R.D., Umar Y.A., Hafiz. (2015). Impact of Organizational Climate on Job Satisfaction and Organizational Commitment in Education Sector of Pakistan. American Journal of Mobile Systems, Applications and Services, 1(2), 102-109.

Focht, A., \& Ponton, M. (2015). Identifying Primary Characteristics of Servant Leadership : DELPHI STUDY. International Journal of Leadership Studies, 9(1), 44-61.

Gibson, James L., Ivancevich, John M., Donnelly, James H. Jr., dan Konopaske, Robert. (2012). Organizations: Behavior, Structure, Processes, Fourteenth Edition. Singapore: McGraw-Hill.

Griffin, Ricky W. (2013). Management: Principles and Practice, Eleventh Edition. United States: SouthWestern Cengange Learning.

Sutarto, W. (2010). Psikologi Industri dan Organisasi: Dalam suatu Bidang Gerak Psikolog Sumber Daya Manusia. Jakarta: Kencana.

Icha, A., Jaya, U. P., Soerjoatmodjo, G. W. L., \& Jaya, U. P. (2018). Membangun Komitmen Organisasi. (August). https://doi.org/10.12737/4477

Gibson, J.L, John M.I., James H.D. Robert K. (2013). Organizational Behaviour, Structure, Processes, Thirteenth Edition, McGraw-Hill International.

Kreitner, R. \& Kinicki, A. (2010). Organizational Behavior”, 9 The edition. New York: McGraw-Hill/Irwin. 
Luthans, F. (2011). Organizational Behavior: An EvidenceBased Approach, Twelfth Edition. New York: McGraw-Hill/Irwin.

McShane, S.L., Marry \& Von G. (2018). Organizational Behavior. Edition. Emerging Realities for the Workplace Revolutions, McGraw-Hill Irwin.

Meithiana, I. (2017). Kepuasan Kerja Dan Kinerja Karyawan Tinjauan dari Dimensi Iklim Organisasi, Kreativitas Individu, dan Karakteristik Pekerjaan.

Mowday. (2017). Affective Organizational Commitment and Job Satisfaction: A Cross-National Comparatove Study. Public Administratuon Journal.

Robert, G. E. (2015). Christian Scriture and Human Resource Management: Building A Path To Servant Leadership Through Faith. New York: PALGRAVE MACMILLAN.

Robbins SP, dan Judge. (2007). Perilaku Organisasi, Alih Bahasa Drs. Benyamin Molan. Jakarta : Salemba Empat

Spears, L.C. 2010. Character and Servant Leadership: Ten Characteristics of Effective, Caring Leaders. The Journal of Virtues \& Leadership, 1(1), 25-30.

Sopiah.(2008). Perilaku Organisasi. Yogyakarta: Andi

Vania, C.P. \& Roy, S. (2013). Pengaruh Servant Leadership dan Komitmen Organisasional Karyawan Terhadap Organizational Citizenship Behavior pada Blue Bird Group Surabaya. Jurnal Agora. 1(3): 1-12.

Zakeer A., Allah, N.I.K. (2016). Leadership Theories and Styles: A Literature Review. Journal of Resources Development and Management, 16(January), 1-8. 